http://dx.doi.org/10.12775/szhf.2015.033

BŁAŻEJ BAsZCZAK

Uniwersytet ZielonogórsKi, ZielonA GóRA

BLAISE-B@O2.PL

\title{
Bycie jako zdarzenie. Filozofia Hegla w interpretacji Jeana-Luca Nancy'ego
}

Pozycja Hegla we współczesnej filozofii francuskiej jest dość szczególna, aczkolwiek recepcja jego myśli zmienia tu swój charakter nieomal z każdym kolejnym pokoleniem filozofów ${ }^{1}$. Znany badacz współczesnej filozofii francuskiej Vincent Descombes postrzega to następująco:

W roku 1930 Hegel był filozofem romantycznym, od dawna odrzuconym przez postęp naukowy [...]. W roku 1945 Hegel stał się osiągnięciem szczytowym filozofii klasycznej i początkiem wszystkiego, co najnowocześniejsze. [...] W roku 1968 wszystko, co nowoczesne [...] jest wrogie Heglowi²

Te wręcz dialektyczne przemiany wizerunku Hegla związane są z działalnością konkretnych interpretatorów, którzy różnie oceniali twórczość autora Fenomenologii ducha, a różnice te wywierały potem istotny wpływ na kolejne pokolenia filozofów. Zmianę wizerunku Hegla, jako twórcy ostatniego i na pozór anachronicznego systemu filozoficznego, zapoczątkował Alexandre

\footnotetext{
${ }^{1}$ Ta ewolucja pozycji Hegla na współczesnej, francuskiej scenie filozoficznej została obszernie opisana między innymi w książce: B. Baugh, French Hegel: From Surrealism to Postmodernism, Routledge, New York 2003.

${ }^{2}$ V. Descombes, To samo i inne. Czterdzieści pięć lat filozofii francuskiej (1933-1978), przeł. B. Banasiak, K. Matuszewski, Warszawa 1997, s. 18.
} 
Kojève wykładami wygłoszonymi w École Practique des Hautes Études w latach 1933-1939, które opublikowano w roku $1947^{3}$. Równie wielki wpływ wywarły w tym względzie poświęcone autorowi Fenomenologii ducha seminaria Jeana Hyppolite'a prowadzone w Collège de France zaraz po II wojnie światowej. Jak zauważa polski filozof Marek Kwiek:

Hegel Hyppolite’a i Kojève’a wprowadził z wielką mocą na francuską scenę filozoficzną pojęcie zmiany i postępu w historii: zmiany w historii mogły być rozumne, a prowadzące do nich programy polityczne mogły być legitymizowane przez filozofię. Heglowska filozofia historii była w stanie nadać w powojennej Francji sens zmianom uważanym za konieczne w teraźniejszości ${ }^{4}$.

Tymczasem wielu uczniów, słuchaczy i czytelników Hyppolite’a i Kojève’a jak Michel Foucault, Gilles Deleuze, Jacques Derrida i Emmanuel Lévinas swoją postawę filozoficzną określało jako próbę uwolnienia się od Hegla. Jak sformułowała to Małgorzata Kowalska, autorka rozprawy na ten temat, proces rozpadu heglizmu w filozofii francuskiej rozpoczął się od drugiej połowy XX w. Według niej:

W istocie jest to myśl, której znakomita część daje się określić jako poheglowska i antyheglowska. Poheglowska nie w tym trywialnym sensie, iż chronologicznie pojawia się po Heglu, ale dlatego, że świadomie wobec filozofii Hegla się sytuuje i określa, że [...] żywi się Heglowskimi widmami. Antyheglowska zaś oczywiście dlatego, że chociaż w głębszej warstwie jej stosunki z Heglem bywają bardzo złożone, przynajmniej na poziomie ogólnych deklaracji z reguły określa się wobec niego negatywnie. [...] W rzeczy samej, od Bataillea po Derridę, przez Sartre’a, Foucaulta, Althussera, Lévinasa, Deleuze’a i Lyotarda, francuscy myśliciele wciąż na nowa podejmują krytykę Hegla ${ }^{5}$.

Fakt, że ową krytykę podejmowali, świadczy oczywiście o ich swoistym, mniej lub bardziej zakamuflowanym, uwikłaniu w heglizm, w tym przypadku traktowanym jako negatywny punkt odniesienia filozoficznego. Próba uwolnienia się od Hegla to próba zastąpienia myślenia dialektycznego niedialektycznym, zwrócenia uwagi na to, co inne (zarówno w sensie ontologicznym,

\footnotetext{
${ }^{3}$ Polskie wydanie: A. Kojève, Wstęp do wykładów o Heglu, przeł. S. F. Nowicki, Warszawa 1999.

${ }^{4}$ M. Kwiek, Dylematy tożsamości. Wokół autowizerunku filozofa w powojennej myśli francuskiej, Poznań 1999, s. 12.

${ }^{5}$ M. Kowalska, Dialektyka poza dialektyką. Od Bataille’a do Derridy, Warszawa 2000, s. 5-6.
} 
jak i etycznym), a także akcentowanie tego, co odrzuca prawo Heglowskiej tożsamości na rzecz różnicy, regułę sprzeczności zaś na rzecz powtórzenia.

W taką, poheglowską, choć nie antyheglowską perspektywę interpretacyjną wpisał się również Nancy. Tym, co różni jego spojrzenie na Hegla od wymienionych wcześniej filozofów jest to, że dla Nancy'go autor Nauki logiki nie zamyka, lecz właśnie otwiera współczesność. W tym sensie pisanie o Heglu, krytyka jego myśli ma na celu nie tyle uwalnianie się od jego filozofii, ile jej rehabilitację, nadawanie jej nowoczesnego wymiaru. Takie ogólne przesłanie mają dwie książki filozofa na temat Hegla. Pierwsza to La remarque spéculative (un bon mot de Hegel) (1973), w której starał się ukazać kilka technicznych terminów filozofii Hegla, przede wszystkim klasyczny już termin die Aufhebung w nowym świetle. Druga to Hegel. L’inquiétude du négatif (1997), w której próbuje dokonać bardziej całościowego omówienia refleksji niemieckiego myśliciela. W Polsce filozofią Nancy’ego i jego recepcją Hegla zajmowała się Małgorzata Kwietniewska, u niej to czytamy:

Wbrew pierwszemu wrażeniu, jakie może sprawiać ten erudycyjny, podparty fragmentami dzieł Hegla tekst, Linquiétude du négatif nie jest ani tradycyjnie akademickim omówieniem filozofii Hegla, ani też mniej lub bardziej wierną ekspozycją heglizmu. Autorowi chodzi przede wszystkim o ustalenie szeregu zbieżności między wymową różnych fragmentów tekstu Heglowskiego z filozofią najnowszą, a więc taką, której on sam czuje się reprezentantem. Rzecz idzie zatem o nieodrzucanie każdej niekanonicznej interpretacji pod pretekstem arbitralności, gdyż pewna ich liczba wcale nie przeinacza wymowy pierwotnej, lecz dokonuje przemyślanej transpozycji („uplastycznienia”) sensu w jego nowym ujęciu. O taką wolność lektury [...] Nancy będzie nieustannie apelował w swoich dziełach ${ }^{6}$.

W innym zaś miejscu polska badaczka dodaje:

W odczytaniu Nancy'ego Hegel jawi się jako myśliciel o żywej inteligencji, błyskotliwy, wybiegający daleko poza konceptualne schematy swojej epoki. Jemu to bowiem zawdzięczamy otwarcie przestrzeni na Abgrunt, czyli brak pierwszego fundamentu zarówno w sferze ontycznej, jak i epistemologicznej

${ }^{6}$ M. Kwietniewska, Jean-Luc Nancy. Dekonstrukcja wobec tradycji, Łódź 2013, s. 46-47. Szersze omówienie tej rozprawy Nancy'ego chociażby w artykule: S. Lumsden, Reason and the restlessness of the Speculative: Jean-Luc Nancy's reading of Hegel, „Critical Horizons”, vol. 6, s. 205-224.

${ }^{7}$ M. Kwietniewska, Jean-Luc Nancy - Na granicy, „Nowa Krytyka”, 2002, nr 13, s. 203. 
W tym znaczeniu Nancy nie przeciwstawiał się więc samemu Heglowi, lecz określonym interpretacjom Hegla, według których był on twórcą statycznego systemu. Ujmując inaczej, autor L'inquiétude du négatif starał się wyeksponować u Hegla to, czego być może on sam do końca nie dopowiedział, po to, by ukazać potencjał jego myśli i jego aktualność w tworzeniu nowego ujęcia metafizyki. Czytał Hegla jako autora nowatorskiego, być może bardziej nowatorskiego niż sam Hegel by się tego spodziewał, dekonstruował jego system Heglowskimi pojęciami. W tym sensie dla Nancy'ego Hegel jest nie tyle myślicielem totalności i systemu, ile raczej ruchu i tożsamości jako aktywności. W La remarque spéculative francuski filozof nie podjął się interpretacji Heglowskiego systemu filozoficznego jako takiego, lecz wskazywał na konieczność jego „plastycznego” odczytania. W ten sposób

...czytelnik Hegla znajdzie się (a dzieje się tak ciągle za sprawą osobliwego ruchu, a w każdym razie ruchu, który nie znalazł własnego sposobu artykulacji) $\mathrm{w}$ sytuacji przeniesienia w pismo tekstu filozoficznego [...], a więc w jego $w y$ kład: tak więc powtarzanie lektury ma wejść teraz w rolę wykładu, stając się plastycznościa ekspozycji. A zatem to plastyczność jest owym wykluczeniem (interdyktem? przewrotem? mutacją? transmutacją?) siatki zwyczajnych odniesień między częściami dyskursu - jest inną gramatyką. Tak więc czytanie Hegla okazuje się pisaniem go na nowo - a jeśli nie, to przynajmniej plastycznym ponawianiem wykładu.

Plastyczne czytanie tekstu nie oznacza jego głębszego odczytania czy lepszego zrozumienia, lecz rozpoznanie tego, czego w nim brak, gdyż nie zostało napisane, czyli uchwycenie tekstu w całkiem inny sposób. Na tym polega plastyczne powtarzanie lektury. Tworzy ono dość osobliwą strategię interpretacyjną, która nie zakłada niczego prócz konieczności powtórnego czytania. $\mathrm{W}$ ten sposób tekst ulega przemieszczeniu czy też rozregulowaniu.

W tym poczuciu utraty - zaznaczał Nancy - w pomieszaniu, będziemy już tylko czytać lub zapisywać odstęp, przemieszczenie..., widzieliśmy bowiem, że to właśnie ten odstęp wytwarza w tekście Hegla wspomniane pomieszanie albo - jeśli tak zechcemy - rodzaj degradującej zmiany, w trakcie której dało się zauważyć, jak zarysowuje się konieczność innej gramatyki, innego typu zdań.

${ }^{8}$ J.-L. Nancy, Preambuła, czyli wprowadzenie do Hegla, przeł. M. Kwietniewska, „Nowa Krytyka”, 2002, nr 13, s. 211-212. Artykuł ten jest tłumaczeniem wprowadzenia do dzieła Nancy'ego La remarque spéculative (un bon mot de Hegel), Paris 1973. 
A skoro cały system środków ostrożności okazał się bezużyteczny, trzeba - wyrzekając się tym razem wszelkiej ostrożności - czytać wszystko to, co inne, czyli innego Hegla w Heglu, co oczywiście oznacza, że trzeba go czytać inaczej [... $]^{9}$.

W takim odczytaniu Hegla nie chodzi o tworzenie dowolnych, arbitralnych interpretacji, lecz o próbę nieograniczania się do zdań składających się na jego dyskurs. Dzięki temu można rozpoznać innego Hegla w Heglu, coś, czego być może on sam nie wypowiedział, lecz co - jak powiada Nancy - nadaje jego dyskursowi plastyczność. Jest to dekonstruowanie systemu pojęciami pochodzącymi wprost $\mathrm{z}$ jego ponownej lektury. W tym sensie czytanie nie jest ani pasywne, ani aktywne, ale jest działaniem zarówno receptywnym, jak i tworzącym.

Zgodziwszy się całkowicie z Heglem w sprawie nieodzowności powtarzania lektury filozoficznej - zaznacza Kwietniewska - Nancy posuwa się dalej, uznając, iż najlepiej jest taki tekst napisać niejako od nowa [...]. Siłą rzeczy odnosi się to również do tekstów samego Hegla, co w konsekwencji prowadzi do „uplastycznienia”, czyli przeformułowania ich zewnętrznej i najbardziej narzucającej się wymowy [...]. Mówiąc jeszcze inaczej - czytając Hegla, należałoby poddać „(w)zniesieniu” jego własną filozofię, to znaczy przeczytać to, co w niej inne, uzewnętrznione i niepokojąco negatywne ${ }^{10}$.

Innymi słowy Nancy zwracał większą uwagę na sposób, w jaki system jest prezentowany niż na jego prawidłowość argumentacyjną. Akcentował sam ruch, w którym następuje zarówno przemieszczenie, jak i ponowne rozpoznanie tekstu.

Taką dekonstrukcyjną strategię różnicy i powtórzenia zastosował Nancy wobec rozpoznawanej w systemie Heglowskim kategorii zdarzenia w napisanym wiele lat później eseju Nieoczekiwaność zdarzenia ${ }^{11}$, będącym jedną

\footnotetext{
9 Tamże, s. 217.

${ }^{10}$ M. Kwietniewska, Jean-Luc Nancy... dz. cyt., s. 46.

${ }^{11} \mathrm{~W}$ oryginale tytuł brzmi Suprise de lévénement i jak pisze tłumaczka tego tekstu na język polski, Małgorzata Kwietniewska, „francuskie słowo la suprise oznacza zaskoczenie, zdumienie, zdziwienie, a także niespodziankę, tak więc zdarzenie zaskakuje i jest nieoczekiwane, ale nie chodzi tu o jakieś jego wirtualne cechy, tylko o 'tu i teraz' zdarzenia $w$ akcie, dlatego zdecydowałam się tłumaczyć ten termin dwojako: tam, gdzie pozwalają na to względy merytoryczne i stylistyczne mówię zaskoczenie, w pozostałych przypadkach posługuję się neologizmem nieoczekiwaność". J.-L. Nancy, Nieoczekiwaność zdarzenia, przeł. M. Kwietniewska, „Principia”, 2001, nr 30-31, s. 15, przypis 1.
} 
z partii książki Être singulier pluriel (1996). W odczytaniu brytyjskiego znawcy dekonstrukcji filozoficznej, Stuarta Barnetta:

To, co interesowało Nancy’ego, to rozróżnienie, które uczynił Hegel pomiędzy poznaniem prawdy a 'zdarzeniem' prawdy - jej narracyjną prezentacją. Jest to rozróżnienie, które otwiera możliwość myślenia zdarzenia - wydarzenia prawdy. Hegel zatem ustanawia dla filozofii zadanie zrozumienia nie tyle prostej prawdy, co prawdy zajmującej miejsce, zdarzenia prawdy. Musimy podążać za Heglem [...] w myśleniu zdarzenia nie jako czegoś odrębnego, lecz jako nadejścia prawdy $[\ldots]^{12}$.

Dlatego swoje rozważania na temat ontologii zdarzenia Nancy rozpoczął od interpretacji fragmentu myśli Hegla zawartej w jego Nauce logiki. Brzmi on następująco:

Filozofia jednak nie ma być opowiadaniem o tym co się dzieje, lecz poznawaniem tego, co w tym, co się dzieje, jest prawdziwe, aby następnie w oparciu o tę prawdę pojęciowo ująć to, co w opowiadaniu występuje jako zdarzenie ${ }^{13}$.

Innymi słowy, Nancy uznał, że nie chodzi tu o rozpoznanie zadania filozofii jako pojęciowego uchwycenia tego, czego zdarzenie jest tylko zjawiskiem. Zgodnie z takim ujęciem pojęcie tego czegoś kładzie bowiem fundament pod wszelką nieokreśloność, wszelką różnicę i każdą formę zewnętrznego urzeczywistniania się. Nancy twierdzi raczej, że Hegel chciał poznać prawdę tego, co się odbywa, co się zdarza, zaś filozofia ma pojęciowo ująć owo odbywanie się jako takie. Kwietniewska komentuje ten wątek w następujący sposób:

W takim ujęciu to nie byt substancjalny, lecz jedynie to, co zdarza się pomiędzy bytami w sferze wyznaczanej przez ich wzajemne odniesienia, stanowi centrum heglowskiego projektu. A tym, czego często nie zauważają tradycyjni komentatorzy Hegla, jest - zdaniem Nancy'ego - realizowane w jego filozofii doświadczenie aktualności mnogich relacji, zwłaszcza relacji podmiotu do samego siebie. Co prawda zdać sprawę z takiego doświadczenia można tylko w czasie, czyli w porządku historycznym, ale ono samo wykracza poza zwyczajnie rozumianą historię. Doświadczenie aktualności nie tyle dzieje się w historii,

${ }^{12}$ S. Barnett, Hegel before Derrida, [w:] S. Barnett (ed.), Hegel after Derrida, London and New York 1998, s. 30.

${ }^{13}$ G. W. F. Hegel, Nauka logiki, t. 2, przeł. A. Landman, Warszawa 1968, s. 366. 
ile jest historią. Całość tej historii rozsnuwa aktualność we wszechobecności teraźniejszości ${ }^{14}$.

$\mathrm{W}$ ten sposób, starając się uchwycić prawdę samego odbywania się, zdaniem Nancy’ego, niemiecki filozof zainaugurował współczesność, czyli otwarcie myśli na zdarzenie jako takie - na prawdę zdarzenia, która ma formę narracyjną (w języku niemieckim używa tu Hegel słowa Geschehen). W konsekwencji „pragnie on pomyśleć istotę tego, co - dokładnie rzecz biorąc - wymyka się logice istoty w znaczeniu substancji, podmiotu lub podstawy na korzyść logiki «zdarzania się», którego istota w całości mieści się w 'poruszaniu' polegającym na braku trwania"'

Chodzi tu więc o inny rodzaj prawdy, prawdy jako Geschehen, która wymyka się ujarzmieniu w jakiejś esencjonalności, substancji czy podmiocie. Nie ma to być prawda unieruchomiona w pojęciu, lecz taka, której zdarzenie jest jej byciem - po francusku powiedziałoby się il y $a$, a nie il est. Jak zauważa Nancy, oba te słowa oznaczają ,jest", ale drugie bardziej uwydatnia sam charakter odbywania się bycia, i może znaczyć mieć-miejsce, czyli właśnie mieć zdarzenie bycia, które jest czymś całkiem innym niż substancja, podmiot lub podstawa bytu.

Nancy zakłada, że bycie nie może po prostu być, wtedy bowiem nic nie mogłoby się zdarzyć i nie byłoby żadnego myślenia. Zaznaczał, że gdyby „bycie po prostu było, nic by się nie zdarzyło i nie byłoby również myślenia. Toteż 'potrzeba' nie jest wyrażeniem prostej immanentnej konieczności (natury lub przeznaczenia). Sama konieczność może być tylko stanowczą odpowiedzią myślenia na niepewność bycia - niepewność, zawieszenie, napięcie: to tam właśnie myśl zostaje zaskoczona"16.

Bycie, jako to, co „jest” nie jest wyłącznie prostą, immanentną koniecznością. Raczej sama ta konieczność może być tylko odpowiedzią myślenia na niepewność bycia, na to, że jest ono zaskakiwane.

Wedle Nancy’ego chodzi tutaj nie tyle o jakąś koncepcję niespodziewaności, ile o samo pomyślenie tego, w jaki sposób myśl może być zaskakiwana i jak to się dzieje, że właściwie nie ma rzeczywistej myśli bez jej niespodziewanego zdarzenia. Filozofowanie polegałoby zatem na tym, że jest ono myśleniem zaskoczonym. Nancy odwołuje się tutaj do klasycznego filozoficzne-

\footnotetext{
${ }^{14}$ M. Kwietniewska, Jean-Luc Nancy, dz. cyt., s. 47-48.

${ }^{15}$ J.-L. Nancy, Nieoczekiwaność zdarzenia, dz. cyt., s. 20.

${ }^{16}$ Tamże, s. 35.
} 
go toposu „zdziwienia”, zawartego w Metafizyce Arystotelesa. Filozofia rodzi się ze zdziwienia. Cóż to oznacza? Najczęściej interpretuje się ten motyw tak, że filozofia powstaje z ciekawości, stawiania sobie pytań i jest swoistym brakiem wiedzy pewnej, i niepodważalnej. Nancy uważa, że zdziwienie związane jest z samym usposobieniem do wiedzy, do Sophia i że znajduje się już ono w pierwiastku wiedzy. Jeszcze inaczej mówiąc, sama Sophia zawiera w sobie aspekt zdziwienia, a dostęp do niej jest nieodróżnialny od dostępu do jakiejkolwiek innej sfery rzeczywistości. Pozostawienie tego aspektu zdziwienia wywołuje nieustające zaskoczenia w sercu Sophia, i jak sądził filozof, jest dla niej momentem konstytutywnym. W ten sposób, dzięki temu dynamicznemu aspektowi zdziwienia, mamy wiedzę, która nie jest podporządkowana niczemu, żadnej trwałej i niezmiennej istocie, istnieje zaś jako swoje własne wyłanianie się. To wyłanianie się, sam ten proces stanowi prawdziwy przedmiot wiedzy, jeśli w ogóle ma ona jakiś przedmiot. Dlatego pomyślenie zdarzenia wymaga tego, że sama myśl może i musi być również zaskoczona przez nieoczekiwaność zdarzenia myślenia. Ale, jak stwierdza Nancy, nawet koncept zaskoczenia będzie musiał być zaskoczeniem. Zaskoczenie w miejsce esencji. Sam Nancy wyraża to słowami:

Sophia powinna zaskakiwać samą siebie, zaskoczenie powinno być „wiadome" - powinno się je wiedzieć. W ten sposób niespodziewaność zdarzenia byłaby nie tylko sytuacją graniczną dla wiedzy dotyczącej bytu, ale również jej ostateczną formą i celem. Od zarania filozofii aż do jej kresu, kiedy znów wprowadza się do gry początek - co też ma swoją cenę - owa niespodziewaność byłaby jedyną możliwą stawką - stawką nieskończoną w dosłownym znaczeniu ${ }^{17}$.

Chodzi zatem o to, by pozostać $\mathrm{w}$ tym momencie zdziwienia, który jest zdarzeniem, tak, aby nadal utrzymywać ową niespodziewaność, nieprzewidywalność zdarzenia, a dzięki temu i samej myśli, która dla filozofa powinna być zawsze zaskoczeniem.

Zdarzenie nie jest więc tu usytuowane poza przestrzenią poznawalności czy wypowiadalności. Nie jest jakąś mistyczną kategorią, czy pojęciem, które można określać wyłącznie w formie teologii negatywnej. Dlatego Nancy nie traktuje zdarzenia jako kategorii czy metakategorii odseparowanej od bytu, lecz raczej jako coś, co warunkuje jego kategoryzację, po to, żeby „go wypowiedzieć, aby nań nakierować, aby przywołać byt w miejsce, na które wynosi

17 Tamże, s. 23. 
go niespodziewaność jego nadejścia" ${ }^{18}$. Zdarzenie jako odbywanie się, jako pojawienie się, $\mathrm{w}$ sensie fenomenologicznym nie jest jednakże "przedstawialne”, co nie znaczy, że jest „nieprzedstawialne”. Chodzi tu o niemożliwość przedstawienia teraźniejszości na styku z samą teraźniejszością. Nie istnieje bowiem coś takiego jak „zdarzenie jako takie”, bo nie jest ono czymś, co można pokazać, lecz jedynie czymś, co się zdarza. Również w wymiarze czasowym owo nieoczekiwane nadejście jako samo odbywanie się, jako uprzestrzennienie otwiera czas na formę skoku i zerwania.

Nie jest to jednak zerwanie z czasowym continuum, które byłoby wprzód ustanowione, lecz zerwanie jako czas, tzn. jako to, co nie dopuszcza niczego z góry założonego, a nawet - i zwłaszcza - żadnego założenia, a zatem uprzedniości czasu wobec samego siebie ${ }^{19}$.

Tym właśnie jest niespodziewaność. Jak zaznaczał Nancy, chodzi tu nie o żadną innowację bytu, który porównywałby się z bytem już zastanym, lecz o skok teraźniejszości jako przebywania lub uobecniania, urodzin i śmierci, które nie tyle są, ile dokonują właśnie „skoku w byciu”. Sam skok należy ujmować jako skok myśli, gdyż to myśl go dokonuje, odczuwając przy tym samą siebie jako zaskoczenie. Sama jest zaskoczeniem nie dającym się oddzielić od bycia. W ten sposób zaś zdarzenie i myśl stają się tym samym.

W tym momencie możliwy jest początek refleksji o zdarzeniu jako takim, czyli o ontologii zdarzenia, która podkreśla sam motyw otwarcia na to, co nieoczekiwane, i nieprzewidywalne. Dla Nancy'ego sama natura zdarzenia uwarunkowana jest przez nieoczekiwaność. Między byciem, które jest, a zdarzeniem bycia, następuje rozdźwięk związany z przerwaniem, pęknięciem bytu. Jak pisał Nancy:

Między byciem a tym, co jest, ma miejsce niezgoda: bycie jest w rozdźwięku z obecną, daną, spoczywającą na swoim miejscu bytowością tego, co jest, a to ostatnie jest w rozdźwięku z substancjalną istotowością, która leży u podstaw bycia. Rozdźwięk jest niezgodnością z tym, co uzgadniając bycie z bytem miałoby poluzować napięcie eks-zystowania. Tak oto rozdźwięk czyni zdarzenie: nie-obecność przybywania do obecności i jego absolutna nieoczekiwaność ${ }^{20}$.

\footnotetext{
${ }_{18}$ Tamże, s. 26.

19 Tamże, s. 28.

${ }^{20}$ Tamże, s. 30.
} 
W interpretacji znanego austriackiego politologa i socjologa, Olivera Marcharta:

To jest konflikt pomiędzy byciem jako obecnością, danością, czyli jako byciem substancjalnym, fundującym swoją esencjalność, a zdarzeniem jako czymś nieprzewidywalnym, nieoczekiwanym. Jeszcze raz napotykamy ontologiczną różnicę. Zdarzenie jest opisywane przez Nancy’ego, zgodnie z myślą Heideggera, jako konflikt, czyli Streit w języku niemieckim, albo Austrag, czyli rodzaj rozstrzygnięcia. Dla Nancy'ego rozgrywa się on pomiędzy bytem a istotą bytów, pomiędzy tym, co ontyczne a ontologiczne [...]. Zdarzenie tej różnicy, innymi słowy, jest destrukcyjne dla wszelkiej immanencji i tożsamości ${ }^{21}$.

Pomyślenie zdarzenia wymaga, by myśl mogła i musiała być zaskoczona przez nieoczekiwaność zdarzenia myślenia. Ale, jak twierdzi Nancy, nawet koncept zaskoczenia będzie musiał być zaskoczeniem dla samego siebie. On jest o tyle, o ile jest zaskoczony, o ile jego bycie-obecnym jest niepełne, niedostateczne, o ile nie przedstawia swojego zaskoczenia, choć w nim istnieje. Tak tworzy się tensja, ekstensja skoku, czyli uprzestrzenienie czasu, która nie jest ani przestrzenią, ani czasem, lecz źródłowym chiazmem, który otwiera jedno w drugim.

Dzięki temu zdarzenie zawsze jest jedno i niepowtarzalne, ale nie w sensie numerycznym. Dlatego Nancy porównywał charakter zdarzenia do sposobu istnienia egzystencji. Zdarzenie, podobnie jak egzystencja jest jednostkowością, spójną, która nie rozkłada się na części, ale uczestniczy w istocie zdarzeniowości. Podobnie jak każda egzystencja jest ko-egzystencją, czyli wchodzi $\mathrm{w}$ nieustające relacje $\mathrm{z}$ innymi egzystencjami ${ }^{22}$. W ten sposób ontologia zdarzenia i egzystencji jest relacyjna i modalna.

${ }^{21}$ O. Marchart, Post-Foundational Political Thought: Political Difference in Nancy, Lefort, Badiou and Laclau, Edinburgh 2007, s. 74.

${ }^{22} \mathrm{~W}$ tym miejscu należy zaznaczyć, że przede wszystkim w dyskusji z analityką egzystencjalną Heideggera, Nancy zaproponował własne, oryginalne ujęcie ontologii jako ko-ontologii. Posługując się idiomatycznym zwrotem étre singulier pluriel radykalnie zreinterpretował samo pojęcie substancjalnej esencji bycia, gdyż dla filozofa każda jednostkowa substancja, każde bycie (czyli étre w tym zwrocie) jest zarazem mnogie. I jest ono mnogie samo w sobie, a nie w wyniku rozbicia uprzednio jednolitego bytu, czy esencji bycia. Ta jednostkowa mnogość konstytuuje samą esencję bycia, a jednocześnie przemieszcza i rozbija każdą substancjalną esencję bycia. Dlatego to, co jednostkowe jest zarazem mnogie, a ko-esencja nie jest jakąś odrębną mnogością bytów, ani nie redukuje się do samych tych jednostkowych esencji. Chodzi raczej o podkreślenie relacyjności tego, co istnieje, gdyż każda ko-esencja transformuje bycie, nadaje mu 
Jest tak, że jest zdarzenie, ma miejsce zaskoczenie, a egzystujący byt nie pozostaje na uboczu, ale jest w nie zaangażowany, a zatem wychodzi zeń poruszony, przemieniony. I właśnie na tym polega egzystowanie ${ }^{23}$.

Nieoczekiwaność zdarzenia zapewnia to, że nigdy nie jest ono dane, ale właśnie się zdarza, zaskakuje i rozprasza w jedyne i niepowtarzalne zdarzenia. Dlatego każde zdarzenie jest jedyne, tak samo jak egzystencja, choć istnieje ona jako mnogość zdarzeń. Nancy podkreśla, że

...zdarzenie nie jest czymś, co sytuowałoby się poza obszarem poznawalności oraz wypowiadalności, a jako takie ograniczałoby się jedynie do tego, co w mistycznej negatywności przekracza mowę i wiedzę. Zdarzenie nie jest kategorią ani metakategorią, odseparowaną od bytu. Jest ono raczej na styku $\mathrm{z}$ bytem, stanowiąc konieczny warunek jego kategoryzacji: aby go wypowiedzieć, aby się nań nakierować, aby przywołać byt w miejsce, na które wynosi go niespodziewaność jego nadejścia ${ }^{24}$.

W tym sensie zdarzenie jest czymś wyjątkowym, choć jednocześnie rozproszonym. Albo jeszcze inaczej: jest zarazem jedyne i różne, jednostkowe i mnogie. To że zdarzenia są zaskakiwane, samo jest zaskoczeniem dla myślenia, które stara się je zrozumieć. Słowami amerykańskiego komentatora twórczości Nancy’ego, Benjamina C. Hutchensa: „....filozofia od Hegla, a może nawet od Parmenidesa, zaniedbywała ten «zaskakujący» aspekt ewentualności zdarzenia”25. Nie ma nic w zdarzeniu, prócz zaskoczenia, ale zaskoczenie jest

za każdym razem nowy, zdarzeniowy i mnogi charakter. W tym sensie ontologia staje się pewnym zdarzeniem, otwartym i sfragmentaryzowanym korpusem wielorakich ko-esencji, gdzie zamiast substancji główną kategorią staje się samo zagadnienie nieustającej relacji wzajemnie do siebie odniesionych bytów, które mają ko-esencjonalny wymiar, są byciem-z. Szerzej na ten temat: T. Załuski, Ontologia jako koegzystencjalna analityka «bycia-z», „Analiza i Egzystencja”, 2007, nr 6; S. Critchley, With Being-With? Notes on Jean-Luc Nancy's Rewriting of Being and Time, „Studies in Practical Philosophy”, 1999, vol. 1, no. 1; Ch. Watkin, A Different Alterity: Jean-Luc Nancy's 'Singular Plural', „Paragraph”, 2007, no. 30. W dziełach Nancy'ego zaś ontologia jednostkowo mnoga została opracowana przede wszystkim w: Le partage des voix, Paris 1982; Être singulier pluriel, Paris 1996; Rozdzielona wspólnota, przeł. M. Gusin, T. Załuski, Wrocław 2010.

${ }^{23}$ J.-L. Nancy, Nieoczekiwaność zdarzenia, dz. cyt., s. 33.

${ }^{24}$ Tamże, s. 26.

${ }^{25}$ B. C. Hutchens, Jean-Luc Nancy and the Future of Philosophy, Montreal \& Kingston 2005, s. 58. 
niczym i przychodzi znikąd. Stwarza to pewne aporetyczne napięcie pomiędzy zaskoczeniem a myśleniem.

Nancy traktuje owo nieusuwalne napięcie jako coś, co musi być pomyślane w odniesieniu do sensu, o formę konieczności wobec sensu, jego niemożliwy do pomyślenia rodzaj, który nie może być skonfrontowany z jakimkolwiek jego uobecnieniem, z czymś, co już się zdarzyło, co już istnieje. Cyrkulacja sensu zakłada zaskoczenie przez zdarzenie myślenia ustanowione przez samo zaskoczenie myślenia. Zaskoczenie esencjalne dla każdego zdarzenia jednostkowego i zaskoczenie każdego skończonego myślenia zdarzenia są na równi bezpodstawne i niemożliwe do rozwikłania. Sens prowokuje byt do zdarzania się. Jak pisał Nancy, jest „potrzebą” odpowiadającą na niepewność bycia, w którym myśl zostaje zaskoczona.

Ujmując to w szerszym kontekście, istnieje pewna niezgodność pomiędzy byciem i bytami, pewien spór pomiędzy zdolnością bycia do ufundowania esencjalności bytów, a nieredukowalnością bytów do takiego ufundowania. Rezultatem tej niezgodności nie jest podmiot, który nie mógłby nigdy zostać zaskoczony, lecz taki, który do tego zaskoczenia jest zdolny.

To, co musi zostać pomyślane - twierdzi Nancy - to nie fakt Bycia, lecz to, że Bycie się zdarza. [...]. Myśl jest zatem tą nieoczekiwanością, która jest niczym. Nancy zatem pokazuje w swoim odczytaniu Hegla - które być może samo jest zdarzeniem - że nie tylko ujawnia rolę zdarzenia u Hegla, ale także rolę Hegla w myśleniu o zdarzeniu ${ }^{26}$.

Zdarzenie to myślenie niemożliwego, czyli myślenie czegoś, co nie jest dane ani obecne, choć kształtuje to, co obecne. W tym sensie filozofia dekonstrukcji to pragnienie niemożliwego, czegoś, co w swej istocie jest niemożliwe do pomyślenia.

Podsumowując, warto zauważyć, że to między innymi za sprawą kategorii zdarzenia Nancy odniósł się do tez Jacquesa Derridy zawartych w eseju Struktura, znak i gra $w$ dyskursie nauk humanistycznych. W pracy tej twórca dekonstrukcji filozoficznej przywołał historię pojęcia struktury, które uznał za centralne dla filozofii i nauki Zachodu, gdyż w nim skupia się i zakotwicza tradycja myślenia jako poszukiwanie transcendentalnego punktu odniesienia dla tożsamości i samo-obecności bytu. Derrida pisał:

${ }^{26}$ S. Burnett, Hegel Before Derrida, dz. cyt., s. 30. 
Łatwo byłoby wykazać, że owo pojęcie struktury, a nawet samo słowo struktura jest równie stare jak episteme, czyli zarazem nauka i filozofia zachodnia, i że ich korzenie wnikają w glebę zwykłej mowy, z której gruntu episteme zaraz je pozbiera, by je sprowadzić do siebie w jakimś metaforycznym przemieszczeniu. A jednak, aż do zdarzenia, które chciałbym uchwycić, owa struktura, czy raczej strukturalność owej struktury, choć się nią zawsze posługiwano, zawsze okazywała się zneutralizowana, ograniczona: za sprawą gestu, który polegał na obdarzeniu jej pewnym centrum, na sprowadzeniu jej do pewnego źródła. Owo centrum miało za zadanie nie tylko ukierunkować i zrównoważyć, zorganizować tę strukturę - nie można w istocie pomyśleć struktury niezorganizowanej - ale zwłaszcza miało sprawić, aby organizująca tę strukturę forma ograniczała to, co moglibyśmy nazwać grą tej struktury. Niewątpliwie to centrum struktury, ukierunkowując i organizując spójność systemu, pozwala na grę elementów wewnątrz tej całościowej formy. I dziś jeszcze struktura pozbawiona wszelkiego centrum przedstawia rzecz nie do pomyślenia samą w sobie ${ }^{27}$.

Derrida traktował dekonstrukcję jako rodzaj gry z określonymi filozoficznymi strukturami i przeciwstawiał sobie dwa "typy" myślenia. Jeden opiera się właśnie na „strukturze”, której inne nazwy w dyskursie filozoficznym, to arche, eidos, telos, ousia. Ten typ myślenia to poszukiwanie jakiejś niezmiennej, metafizycznej podstawy, wyznaczonego celu, hierarchiczności bytu, czy bytu jako obecności, jakiegoś „centrum” jako źródła sensu. Natomiast drugi „typ” myślenia dopuszcza możliwość „gry” jako pola nieskończonych substytucji w jakiejś skończonej i zamkniętej całości. Gra narusza niezmienną obecność i wymusza brak absolutnej pewności. Gra doprowadza do owej „rozbiórki” struktury oraz rozmywa filozoficzne marzenia o pełnej obecności bytu, o dającej pewność podstawie, o klarownym początku i kresie. Jednakże ten antystukturalistyczny gest gry może się odbyć tylko w pewnej „strukturalistycznej" ramie odniesienia. Gra ma tylko wskazać ograniczenia totalizującego „typu” myślenia. Derrida podkreślał, że wprowadzenie pojęcia struktury oraz porzucenie źródła i fundamentu nie jest procesem, który można by podsumować jakimkolwiek nowym konsensusem. Ma ono raczej status zdarzenia, czyli pewnego, stałego, ontologicznego niedookreślenia. Chodzi o pewne przezwyciężenie i wywrócenie fundamentu metafizycznego. I ta dwuznaczność oraz wyrafinowanie strategii dekonstrukcyjnej jest jej cechą konstytutywną, którą podjął Nancy. W swoich interpretacjach Hegla, ale tak-

${ }^{27}$ J. Derrida, Struktura, znak i gra $w$ dyskursie nauk humanistycznych, [w:] tenże, Pismo i różnica, przeł. K. Kłosiński, Warszawa 2004, s. 483-484. 
że Kanta, Kartezjusza oraz Heideggera na nowo ich odczytywał, tropiąc w ich tekstach (na wzór dekonstrukcyjnej inwencji i aporetyczności) fragmenty, które podważają stałość kategorii metafizyki. W tym sensie Nancy'ego próba ponownej interpretacji metafizyki obejmuje fundamentalną modyfikację podstaw myślenia filozoficznego. Jednakże porzucenie filozoficznego źródła i fundamentu nie jest procesem, który można by podsumować jakimkolwiek nowym konsensusem. Ma raczej status zdarzenia, czyli pewnego, stałego, ontologicznego niedookreślenia. Chodzi o pewne przezwyciężenie i wywrócenie fundamentu metafizycznego. Derrida nazywał je grą ze strukturą, zaś Nancy owo przezwyciężenie podstaw metafizycznych, u mistrza filozoficznego systemu, czyli Hegla, dokonał za sprawą kategorii zdarzenia, co ciekawe, wytropionej w samym jego dyskursie.

\section{Bibliografia}

Barnett S., Hegel before Derrida, in: Hegel after Derrida, S. Barnett (ed.), London and New York 1998.

Baugh B., French Hegel: From Surrealism to Postmodernism, Routledge, New York 2003.

Critchley S., With Being-With? Notes on Jean-Luc Nancy's Rewriting of Being and Time, „Studies in Practical Philosophy”, 1999, Vol. 1, no.1.

Derrida J., Struktura, znak i gra w dyskursie nauk humanistycznych, [w:] tenże, Pismo i różnica, przeł. K. Kłosiński, Warszawa 2004.

Descombes V., To samo i inne. Czterdzieści pięć lat filozofii francuskiej (1933-1978), przeł. B. Banasiak, K. Matuszewski, Warszawa 1997.

Hegel G. W. F., Nauka logiki, t. 2, przeł. A. Landman, Warszawa 1968.

Hutchens B. C., Jean-Luc Nancy and the Future of Philosophy, Montreal \& Kingston 2005.

Kojève A., Wstęp do wykładów o Heglu, przeł. Ś. F. Nowicki, Warszawa 1999.

Kowalska M., Dialektyka poza dialektyka. Od Bataille’a do Derridy, Warszawa 2000.

Kwiek M., Dylematy tożsamości. Wokół autowizerunku filozofa w powojennej myśli francuskiej, Poznań 1999.

Kwietniewska M., Jean-Luc Nancy - Na granicy, „Nowa Krytyka”, 2002, nr 13.

Kwietniewska M., Jean-Luc Nancy. Dekonstrukcja wobec tradycji, Łódź 2013.

Lumsden S., Reason and the restlessness of the Speculative: Jean-Luc Nancy's reading of Hegel, „Critical Horizons”, vol. 6, 2005. 
Marchart O., Post-Foundational Political Thought: Political Difference in Nancy, Lefort, Badiou and Laclau, Edinburgh 2007.

Nancy J.-L., Etre singulier pluriel, Paris 1996.

Nancy J.-L., La remarque spéculative (un bon mot de Hegel), Paris 1973.

Nancy J.-L., Le partage des voix, Paris 1982.

Nancy J.-L., Nieoczekiwaność zdarzenia, przeł. M. Kwietniewska, „Principia”, 2001, nr 30-31.

Nancy J.-L., Rozdzielona wspólnota, przeł. M. Gusin, T. Załuski, Wrocław 2010.

Watkin Ch., A Different Alterity: Jean-Luc Nancy's 'Singular Plural', „Paragraph”, 2007, no. 30 .

Załuski T., Ontologia jako koegzystencjalna analityka «bycia-z», „Analiza i Egzystencja", 2007, nr 6.

\begin{abstract}
Being as Event: Hegel's Philosophy in the Interpretation of Jean-Luc Nancy

This paper examines Jean-Luc Nancy's interpretation of Hegel, focusing in particular on the category of an event. For Nancy, the closure of metaphysics means among other things the dislocation of the foundationalist of the being and to start thinking about the event as the surprise. The event is characterized by a structural unexpectedness because of its disturbing and surprising nature. That's why being is in conflict with the present, with being's substantial, founding essentiality.
\end{abstract}

Key words: Nancy, Hegel, the event, the surprise, being 